\title{
ANCIENT SEDIMENT STUDIES
}

Investigations of Appalachian Section $^{1}$

Geological Survey of Canada

by W.H. POOLE

Geological Survey of Canada, Ottawa

The Appalachian Section undertakes geological studies and mapping of all geological materials within the folded and unfolded rocks of the Appalachian system in Canada. The objectives of this research are the description, interpretation, and synthesis of the stratigraphy and sedimentology, structure, igneous and metamorphic petrology, tectonic history, and metallogeny of the region, and to relate all rocks and deposits of economic minerals to one another in space, time, and evolution.

During 1964, field investigations in three areas in Newfoundland were completed: gneisses and Devonian strata of Port aux Basques area, Ordovician and Silurian sedimentary and volcanic strata of Gander Lake area, and Devonian granites of Wesleyville area. In northern Nova Scotia, detailed studies were continued in the lower Palaeozoic rocks and granites of the Cobequid Mountains and Antigonish Highlands. Summary accounts of the investigations are carried in Geological Survey Paper 65-1.

\section{Activities in 1964}

W.H. POOLE completed an investigation of the geology of an area in north-central Yukon. He published with D.G. KELLY and E.R.W. NEALE a paper on age and correlation problems in the Canadian Appalachian region in a Royal Society of Canada volume. In a bulletin of Geological Society of America, he published with J. BELAND and R.K. WANLESS a reply to discussion of a paper. He submitted for publication a paper on ages of granites in central New Brunswick. He was appointed acting head of the Appalachian Section until the return of E.R.W. Neale in September 1965.

F.D. ANDERSON completed in collaboration with $\mathrm{H}$. WILLIAMS the investigation of the Ordovician and Silurian sedimentary and volcanic rocks and accompanying intrusions in Gander Lake area, west half,

1

Published with permission of Director, Geological Survey of Canada. 
(2D W 1/2) central Newfoundland to effect correlations between the Gander Lake and Bay d'Espoir Groups and establish relationships with volcanicrich Ordovician strata and the Silurian Botwood Group. Later in the field season, Anderson began detailed structural studies in the Bay d'Espoir slate and phyllite succession in order to interpret the superimposed structures of more than one orogeny. He submitted for publication a preliminary map of Belleoram (IM), southeastern Newfoundland, in which he has integrated localized detailed stratigraphic studies of earlier workers. He began preparation of a memoir on Belleoram geology and revised the edited manuscript of a memoir on western New Brunswick geology.

D.G. BENSON began investigation in the Merigomish area (11 E/9) as part of a continuing program of stratigraphic and structural study of the pre-Carboniferous rocks and granites in the Antigonish Highlands, northern Nova Scotia. These rocks had been regarded as basement complex by earlier geologists mainly concerned with Carboniferous stratigraphy and paleontology. Needed here was a much clearer understanding of the relationships of the Ordovician volcanic and sedimentary rocks, and the more gently folded Silurian arenites. He published a preliminary map of Lochaber area $(11 \mathrm{E} / 8)$, and submitted a manuscript of a memoir on Hopewell area $-(11 \mathrm{E} / 7)$. Both represent investigations on the south side of Antigonish Highlands where a strip of Carboniferous strata separate possible correlative volcanic-rich Browns Mountain Group and volcanic-poor Meguma Group. He was transferred to the Halifax office at the Bedford Institute of Oceanography during the spring of the year.

J.W. GILLIS completed investigation and 4-mile mapping of Port aux Basques area $(110)$, southwestern Newfoundland to provide information on the origin of the gneisses and schists and their stratigraphic relations to known Devonian strata. He completed for presentation to Pennsylvania State University a Ph.D. thesis on Carboniferous stratigraphy of Pictou County, Nova Scotia, and began preparation of a memoir on the Port aux Basques area.

D.G. KELLY continued investigation of the pre-Carboniferous strata and granites in the Cobequid Mountains, northern Nova Scotia. These rocks had been largely neglected by earlier stratigraphers and palaeontologists more concerned with Carboniferous sediments. The area will provide a valuable increment to the tectonic history of the important Bay of Fundy-Cape Breton Island zone. He published with W.H. Poole and E.R.W. Neale a paper in The Royal Society of Canada volume treating age and correlation problems in the Canadian Appalachian region, and submitted a manuscript of a memoir on Baddeck and Whycocomagh areas, Cape Breton Island, in which Carboniferous stratigraphy, tectonics, and petroleum potentialities were treated. With M.O. MACRASEY, he submitted for publication a paper concerned with little known volcanic rocks in Lower Mississippian strata of Cape Breton Island.

H. WILLIAMS with F.D. Anderson completed investigation of the Ordovician and Silurian strata in Gander Lake area ( $2 \mathrm{D} \mathrm{W} \mathrm{1/2),}$ centra1 Newfoundland (see under F.D. Anderson). Later in the season 
Williams studied the granites of the Wesleyville area ( $2 F$ ), northeastern Newfoundland, to outline further the sequence and distribution of multiple intrusions in relationship to regional stratigraphy and tectonics. He published a preliminary map of the Botwood area ( $2 \mathrm{E})$ integrating results of local detailed studies to show the symmetry and facies changes within the Ordovician and Silurian eugeosynclinal rocks. He published a short paper on the isotopic ages on the granites of the area in which isotopic ages are anomalously old for unknown reasons when compared with the stratigraphic ages. In a bulletin of Geological Society of America, he published an abstract of a paper describing the symmetry of the stratigraphy in northeastern Newfoundland, and in the American Journal of Science he published the full paper. He submitted a manuscript of a map of Wesleyville area.

Two current projects of a regional nature:

W.H. POOLE, B.V. SANFORD, D.G. KELLEY, H. WILLIAMS, and W.D. MCCARTNEY are preparing the chapter on Appalachian and St. Lawrence Lowland geology for the new edition of the Geological Survey's "Geology and Economic Minerals of Canada". This edition, the fifth, will emphasis tectonics and rock facies. R.J.W. DOUGLAS is the editor.

H. WILLIAMS and W.D. MCCARTNEY are preparing a paper on the Precambrian rocks of the Appalachian region of Canada for one of several volumes entitled "The Precambrian" being edited by K. RANKAMA.

\section{Selected Publications}

1. Summary reports of activities in field, and in office and laboratory have been published annually for several years. Those available for 1963 and 1964 appear below:

Summary of Activities: Field, 1963, compiled by S.E. Jenness, Geo1. Surv. Can., Paper 64-1, 92 p (1964)

Summary of Activities: Office and Laboratory, 1963, compiled by P. Harker, Geo1. Surv. Can., Paper 64-2, 119 p. (1964)

Summary of Activities: Field, 1964, compiled by S.E. Jenness, Geo1. Surv. Can., Paper 65-1, 166 p. (1965)

2. A few papers dealing with the geology of large parts of the region are listed below:

NEALE, E.R.W., BÉLAND, J., POTTER, R.R., and POOLE, W.H., 1961, A preliminary tectonic map of the Canadian Appalachian region based on age of folding: Bull. Can. Inst. Min. Metal., v. 54, p. $687-694$

POOLE, W.H., KELLEY, D.G., and NEALE, E.R.W., 1964, Age and corre- 
lation problems in the Appalachian region of Canada; in Geochronology in Canada, edited by F.F. Osborne, Roy. Soc. Canada, Spec. Pub1. No. 8, p. 61-84

RODGERS, J., and NEALE, E.R.W., 1963, Possible "Taconic" K1ippen in western Newfoundland; Am. J. Sci., v. 261, p. 713-730

WILLIAMS, H., 1964, The Appalachians in northeastern Newfoundland a two-sided symmetrical system; Am. J. Sci., vol. 262, p. 11371158

WILLIAM R. CHURCH of the UNIVERSITY OF WESTERN ONTARIO is studying, since 1963, the structural history of the White Bay South and Green Bay districts of northeastern Newfoundland. The research is sponsored by the UNIVERSITY OF WESTERN ONTARIO, and financed by the GEOLOGICAL SURVEY OF CANADA.

His present studies are concentrated in five areas with the following aims :

1) to establish the stratigraphic and structural relationships between the Fleur de Lys, Baie Vert, and Mic-Mac Groups in the vicinity of Mic-Mac Lake and Flatwater Pond, and the structural succession of the Fleur de Lys Group between Mic-Mac Lake and Westport.

2) to establish a detailed structural succession between La Scie and Tilt Cove in order to clarify the status of the Cape St. John Group in the vicinity of La Scie relative to the Silurian conglomerates and lavas at Tilt Cove.

3) to compare, by means of structural analysis, the structural histories of the Fleur de Lys, Baie Verte, and Cape St. John's groups in the vicinity of Paquet Harbour and Cape Cagnet.

4) to investigate the apparent inversion of the Fleur de Lys - Baie Verte succession at Seal Cove, Baie Verte.

5) to compare the structure and petrography of the Snooks Arm volcanic group with the Baie Verte volcanic group in the vicinity of Betts Cove.

DR. CHURCH has presented at the recent C.I.M. meeting in Toronto a paper entitled "Structural evolution of North-East Newfoundland: a comparison with that of the British Caledonides". The full paper will be published in the C.I.M. Bulletin. CHURCH compares the structural and metamorphic history of the Upper Proterozoic clastic metasediments of southern County Donegal in northwestern Ireland with metamorphic rocks of the Burlington Peninsula. This important and interesting paper summarizes available information on the structure of northeastern Newfoundland. A summary of this paper with a short list of relevant papers 
follows.

Structural Evolution of North-East Newfoundland:

comparison with that of the British Caledonides

by W.R. CHURCH

University of Western Ontario,

London, Ontario

The British Caledonides and the Newfoundland Appalachian systems have in common: a northwestern foreland region composed of preCambrian gneisses, overlain by Cambro-Ordovician carbonate rocks containing a typical North American fauna; a north-central orthotectonic belt of intensely deformed garnet-grade metamorphic rocks; a south-central belt of Ordovician and Silurian clastic and volcanic rocks; and a south-eastern foreland region composed dominantly of pre-Cambrian volcanics overlain by Upper Proterozoic rocks followed by Cambro-Ordovician clastic rocks bearing a typical European fossil fauna. An important point of similarity between North-East Newfound1 and and the West of Ireland is the occurrence, immediately to the south-east of the north-central metamogphic belts of both regions, of Lower Ordovician spilitic lavas unconformably overlain by Silurian red-bed clastics and volcanics. Opinion in Britain as to the age of the Caledonide orthotectonic metamorphic belt is divided, and ages as varied as pre-Cambrian, Middle Cambrian - Lower Ordovician, and postLower Ordovician have been postulated for the belt. However in the west of Ireland the earliest phase of deformation recognizable in the metamorphic rocks occurred prior to, or within Lower Ordovician times. The metamorphic rocks are also deformed by:a late phase of post-Silurian deformation. Deformation that might be attributable to the Taconic orogeny was much less intense in comparison with the early and late orogenic phases, and produced structures that are essentially paratectonic in style.

The rocks of the Burlington Peninsula, North-East Newfoundland, belong to four groups: the Fleur de Lys Group of clastic metasediments and the Baie Verte Group of spilitic lavas of the metamorphic belt; the Snooks Arm Group of spilitic lavas; and the Cape St. John Group of conglomerates, sandstones, and silicic and mafic lavas. The Fleur de Lys and Baie Verte Groups are unfossiliferous, but are considered by Neale and Nash (1963) to be Ordovician on the basis of the lithologic similarity of the Baie Verte Group to the Lower Ordovician Snooks Arm Group. The Cape St. John Group appears to unconformably overlie the folded Snooks Arm Group, and is therefore considered to be Silurian in age. A comparison of minor structures in the Fleur de Lys, Baie Verte, and Cape St. John Groups along the north shore of the Burlington Peninsula indicates that they have a common structural history, involving at least three phases of deformation. This suggests 